\title{
FINNISH-HUNGARIAN COOPERATION IN BRYOLOGY; MEMORIES FROM EXCURSIONS, CONGRESSES AND RESEARCH WITH PROFESSOR TAMÁS PÓCS
}

\author{
TIMO KOPONEN
}

\begin{abstract}
The paper describes Professor Tamás Pócs' cooperation with Finnish bryologists and other cryptogam taxonomists. Cooperation began with exchange of reprints in 1966 and identification of African bryophyte specimens in 1973. In 1976, Timo Koponen visited Budapest and Eger, and joint work continued during a University of Helsinki Department of Botany student excursion to Tanzania in 1988. Tamás Pócs, then a professor at Sokoine Agricultural University, arranged the logistics for the preparatory visit of four teachers as well as for the excursion itself. Later, Pócs participated in the Congress of Eastern Asiatic Bryology, the EU-funded 'Advanced instruction in bryology and lichenology' (Large Scale Facility) program and the 'Bryophyte Flora of the Huon Peninsula, Papua New Guinea' project organized in Helsinki. He was elected a corresponding member of the Finnish Bryological Society in 2009.
\end{abstract}

Key words: Eger, Helsinki, history, lichenology, liverworts, mosses, mycology, Myxomycetes, Tanzania, Tayloria

Timo Koponen, Botany Unit (Bryology), Finnish Museum of Natural History, P.O. Box 7, FI-00014 University of Helsinki, Finland, and Finnish-Chinese Botanical Foundation, Mailantie 109, FI-08800Lohja, Finland; e-mail: timo.koponen@helsinki.fi

Cooperation between Finnish and Hungarian bryologists began more than 100 years ago. According to Koponen and Piippo (2002), the Hungarian bryologist Istvan Györffy (1880-1959) sent 33 letters to Viktor Ferdinand Brotherus between 1908 and 1928. Györffy was a specialist on the genus Molendoa, and clearly helped identify Molendoa specimens when Brotherus (1929) was writing the 'Musci' section for Symbolae sinicae (Cao \& Koponen 2004; Koponen 2010).

Brotherus' death in 1929 interrupted this cooperation, and 'during and after the Second World War little progress was made in bryology due to prevailing conservatism' (Tuomikoski 1958). Besides Antero Vaarama and Risto Tuomikoski, who did not do bryological research after 1958 (Koponen 2013a), in Finland there were only three elderly bryologists: Hans Buch (†1964), Mauno J. Kotilainen († 1962) and Heikki Roivainen (†1983).

\section{COOPERATION BEGINS}

In Finland a new younger generation of bryologists emerged in the mid-1960s (Koponen 2013b), and in Hungary also, it seems. These young bryologists took a cooperative approach to research and entered into the study of exotic bryofloras. Tamás Pócs was permitted to travel to communist countries such as North Vietnam and Cuba, and later Tanzania, and I went to Japan, Taiwan and Canada, and later New Guinea and mainland China. Some of my students followed me to those places. Others went elsewhere; Jaakko Hyvönen, for example, collected in Tierra del Fuego.

Cooperation between Pócs and me began in 1966 through exchange of reprints. In 1973, Pócs wrote me asking whether I would like to identify some collections from Kilimanjaro, which looked to be either Mniaceae or Splachnaceae. I had sent him a reprint on African Tayloria (Koponen $\&$ Weber 1972). Two of Pócs' specimens turned out to be Brya, but the third was an undescribed species of Tayloria. Aune Koponen (1975) described it as $T$. pocsii, and later (1977) combined it under the genus Brachymitrion as B. pocsii.

An exchange program for scientists had been organized between the Finnish and Hungarian governments, and in 1976 I visited Hungary for 
two weeks as part of this. I studied Mniaceae in Budapest in the Museum of Natural History, and over several days in Eger became acquainted with botanists from Ho Chi Minh Teachers' College. The reception by Tamás and his wife Sarolta, as well as the other staff members, was exuberant, influenced by the ancient Finno-Ugric historical and linguistic connections. Two of Pócs' foreign students were in Eger: Tran Minh from Vietnam and Deisi Reyes Montoya from Cuba. I recall a field excursion in which the participants - two bryologists from the tropics, one man from the temperate zone and another from the cold boreal world - bravely collected bryophytes in the cold and rainy autumn weather. But the atmosphere was friendly and opportunities for continuous cooperation were created.

\section{TOWARDS A MORE COOPERATIVE BRYOLOGICAL} SOCIETY

After World War II, personal contacts between bryologists from communist countries and those on the other side of the Iron Curtain were rather few, and the same was true of contacts even between bryologists from different communist countries. In an attempt to improve this situation, some bryologists from Poland, Czechoslovakia, the German Democratic Republic and Hungary met in Riclef Grolle's home in Jena, and pondered the establishment of a 'Moosforscher-Arbeits-Gemeinschaft in den Sozialistischen Ländern' (Orbán 1979). The community was established, and the first meeting, organized by Tamás Pócs and Sándor Orbán, was held in Eger in 1978. In addition to the participants from communist countries, three westerners were present as observers: Aune Koponen, me, and IAB Secretary S. Robbert Gradstein. The second meeting was held in Poznań in 1980 and the third in Prague in 1982. Nearly 50 bryologists from 12 European countries, including Japan, Canada and the United States, participated in the third meeting (Váňa 1984). There were two participants from Finland, Sinikka Piippo and me. Thus the attempt to promote contact between bryologists from communist countries and those from the 'free world' was a success.

\section{FINNISH EXCURSIONS TO TANZANIA}

On the $1^{\text {st }}$ of January 1986 I was appointed to a professorship in the Department of Botany at the University of Helsinki. One of my duties was to organize student excursions. The traditional excursion targets were to Finnmark in northern Norway and to the Canary Islands. I considered the possibility of taking the students to some more exotic and demanding locations. Tamás Pócs was in Tanzania at the time, posted as a professor at Sokoine Agricultural University financed by NORAD (Orbán 2003) and accompanied by his family. Why not ask whether he could help with the logistics of the planned excursion?

Tamás Pócs accepted our proposal and four Finnish teachers made a preparatory excursion on 14-31 May 1988, guided by Tamás and his wife Sarolta, 'the best safari driver in Tanzania'. The Finnish group consisted of two bryologists, Aune Koponen and me, and two mycologists, Marja Härkönen and Tuomo Niemelä (Fig. 1). Tamás had planned an itinerary and took us to see a number of different vegetation types ranging from mangrove in Tanga to primeval forests on the Uluguru mountains and Mt. Meru (Fig. 2), with savanna and arid vegetation in-between. The students' excursion took place on 4-27 December of that year. The group of fifteen Finnish and two Tanzanian students was guided and helped by Tamás and Sarolta Pócs and their three children, 'Small Poxes' as Tamás referred to them. Without their assistance before and during the journey the field trip would not have been possible. The help provided by Tamás with botanical problems and Mrs. Pócs with practical ones was indispensable. Abel Pócs drove fast but reliably in the second cross-country vehicle of the Pócs family. He and his brother and sister had a sense of humor we very much appreciated.

The teachers' preparatory excursion was financed by the Academy of Finland and the students' excursion by the Finnish Development Agency, which requested a research report. Each student had a research topic, such as collecting specimens of a particular plant group or conducting vegetation studies. Two booklets were published. 


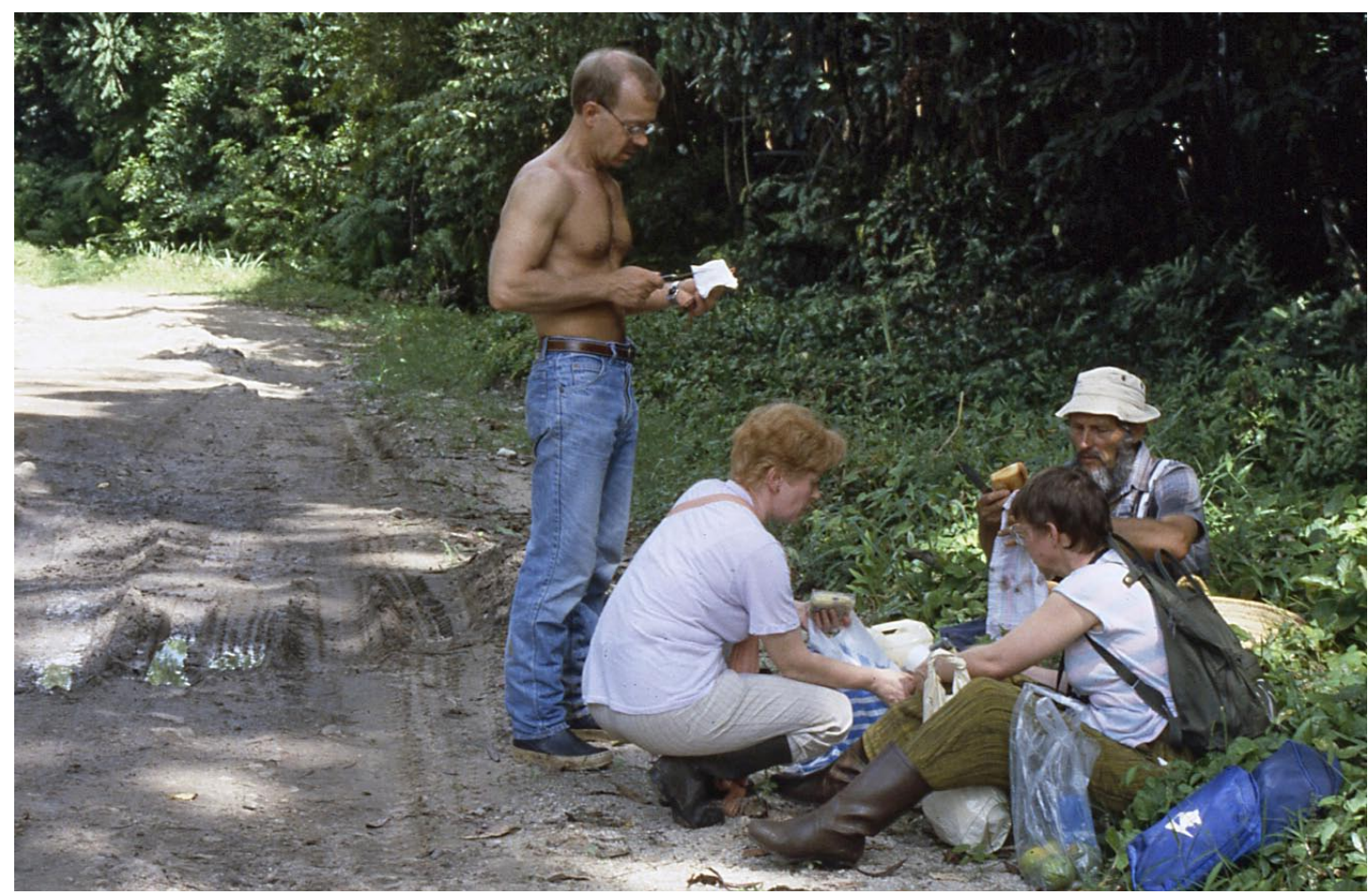

Fig. 1. Lunch break at roadside. From left: Tuomo Niemelä standing, Aune Koponen, Marja Härkönen, Tamás Pócs behind Marja. 1988 Photo T. Koponen.

The first (Nurmi 1990) is mostly in Finnish and contains a diary of the journey and short articles on various Tanzanian topics written by students, as well as four articles by Pócs (1990a, b, c, d). The second report (Koponen et al. 1990) is in English and lists the material collected and the students' research reports.

The mycology group was able to make several subsequent excursions and the woody flora was also studied. Tamás Pócs invariably helped these groups during the time he was stationed in Tanzania. As a result, a mushroom book (Härkönen et al. 2003) as well as a guide to the trees of the Amani Nature Reserve (Junikka et al. 1998) were published. Other published results included Ukkola's (1998) Ph.D. thesis, which dealt with Tanzanian Myxomycetes. Niemelä (2011) published a book on African plants and vegetation. Mattila and Koponen's (1998) study of bryophytes on rotted wood, based on P. Mattila's M.Sc. thesis, and Sanna Laaka-Lindberg's (2004) paper on the ruderal vegetation of roadsides and ditches, were the only bryological results. My applications for additional funding for bryological studies in Tanzania were turned down. Instead, funds for an excursion to Papua New Guinea were approved. In 1981, and D. H. Norris and I collected 17,000 bryophyte specimens there. Before the excursion, Tamás Pócs advised me to pay special attention to epiphyllic liverworts, especially the genus Aphanolejeunea. Study of those specimens initiated a wide-ranging collaborative project involving around 30 bryologists from Finland and nine other countries (Koponen 1990, 2000). Moreover, a course in tropical bryology was arranged in Helsinki (see below).

\section{CONGREss OF EAST ASIATIC BRYOLOGY}

In 1990, the University of Helsinki celebrated its $350^{\text {th }}$ anniversary, and the university authorities hoped that many international congresses could 
be arranged. The then-recently established (in 1987) Finnish Bryological Society and the Department of Botany decided to arrange a Congress of East Asiatic Bryology. The platform for such a meeting was twofold: the tradition of research by the Finnish bryologists S. O. Lindberg (e.g., Russian Far East, Japan) and V. F. Brotherus (Japan, China, South Asia, New Guinea); and the new collecting excursions from Helsinki and cooperation with other bryologists in those places. The society succeeded in getting funding from several sources for participants. Tamás Pócs was invited by the Rector of the University of Helsinki, and the expenses of seven Chinese participants were met by the Finnish-Chinese Botanical Foundation (Gao \& Cao 2010). The proceedings (Koponen \& Hyvönen 1992) lists 62 participants. In addition to presenting a paper (Pócs 1992), Pócs was a member of the Resolutions Committee. The committee resolved that 'this Congress (1) supports and urges the support of all efforts to preserve the forests of Asia, and (2) expresses great concern about the loss of positions in bryology (mosses and liverworts) in the British Natural History $\mathrm{Mu}-$ seum'. Jette Lewinsky (1990) wrote a summary of the events of the Congress.

After the Congress Tamás Pócs was in Helsinki with Sacy Pócs. Marja Härkönen and Tuomo Niemelä arranged a post-congress excursion to Finnish Lapland for them.

\section{RESEARCH IN HELSINKI}

Meanwhile, study of the material collected in New Guinea proceeded, and 54 parts of the series 'Bryophyte flora of the Huon Peninsula, Papua New Guinea' had been published by 1994 (Koponen 2000). One of the remaining problems was the family Lejeuneaceae, and especially the epiphyllous material; the substrates of these liverworts are entire leaves, and there may be more than ten different taxa on a single leaf. An application for funds from the Academy of Finland was successful, and I was able to invite Tamás Pócs

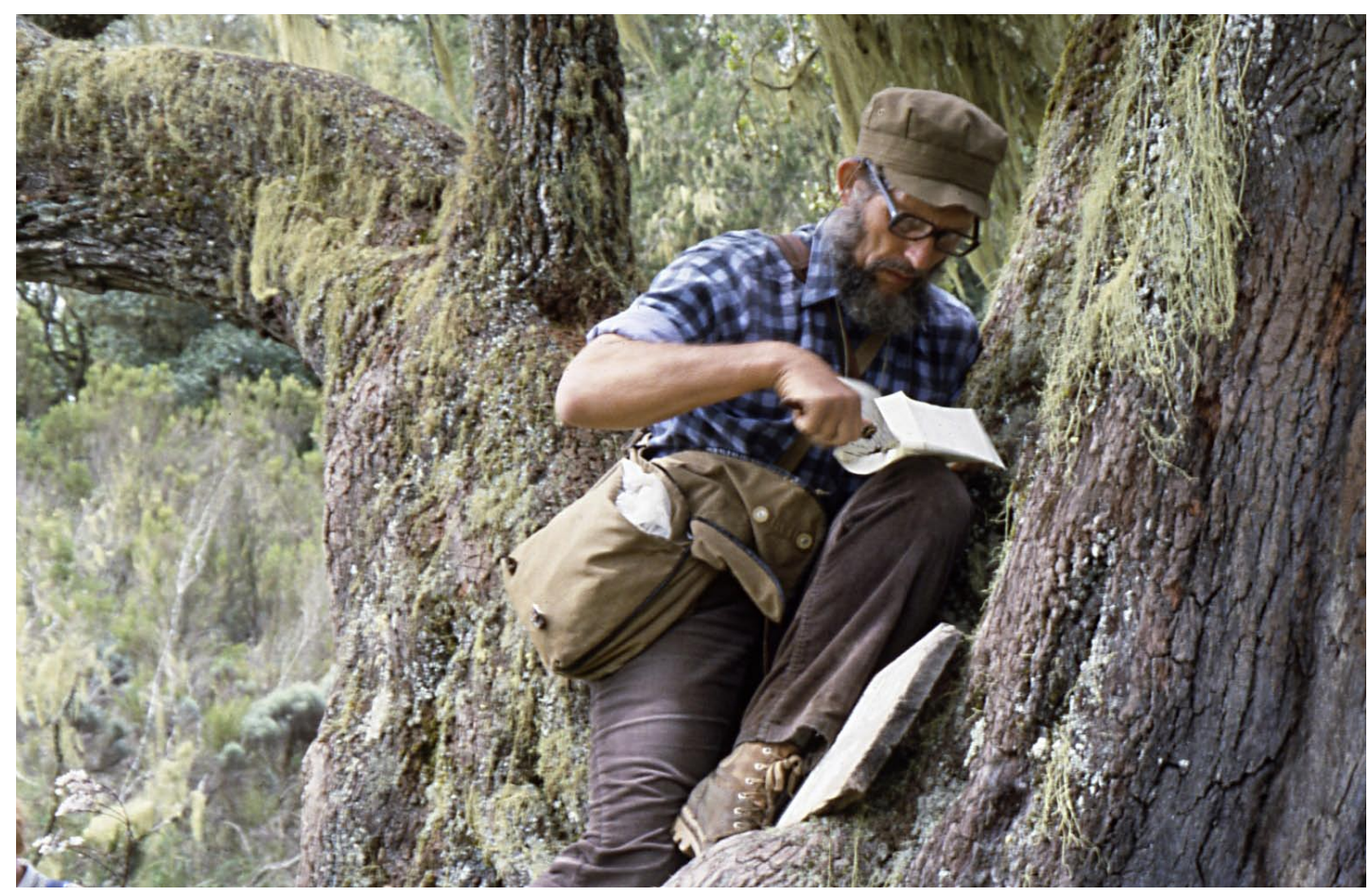

Fig. 2. Tamás Pócs collects bryophytes on tree on Mt. Meru in 1988. Photo M. Härkönen. 


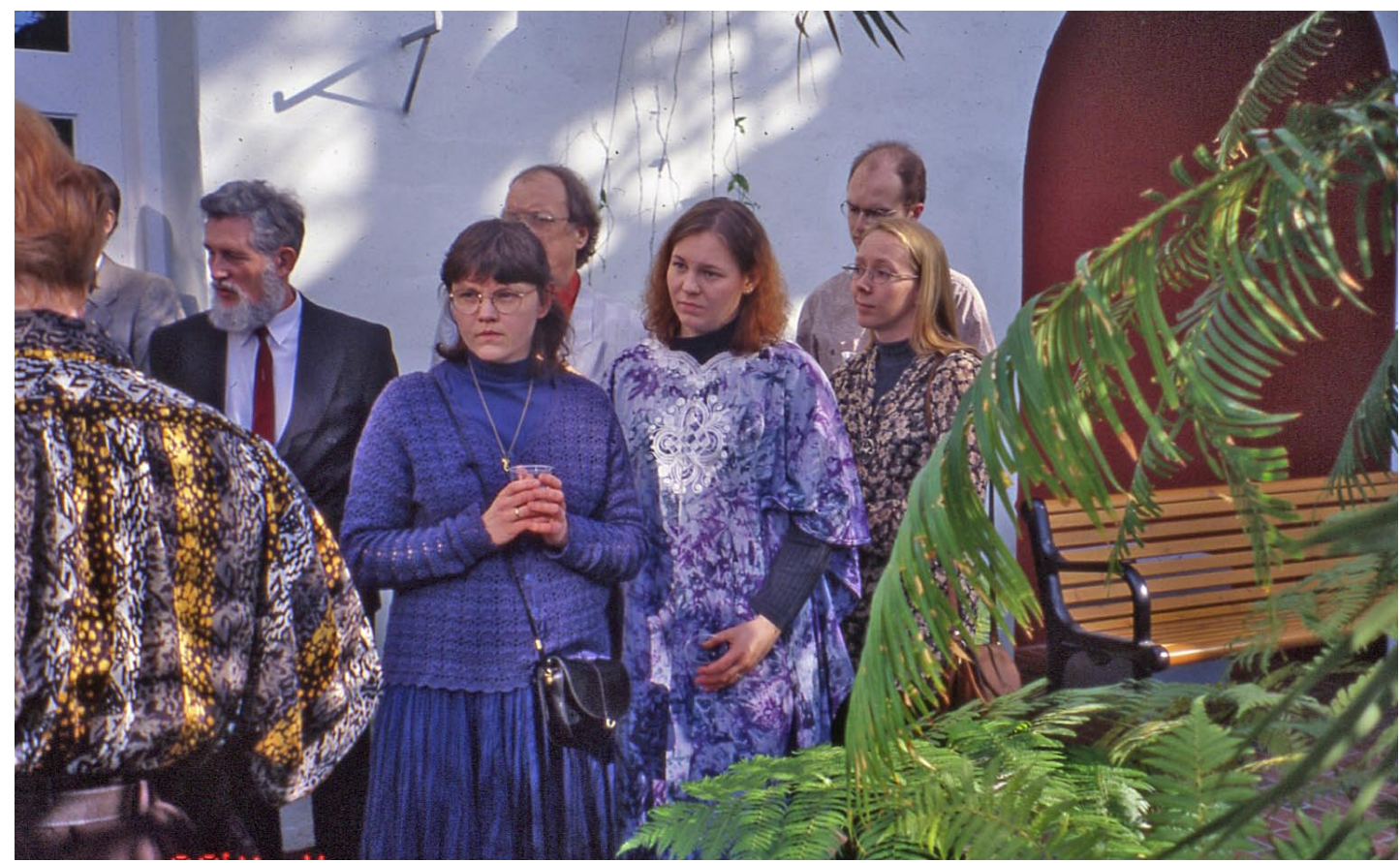

Fig. 3. 'African night in Palm house'. Next to Tamás Pócs are Sanna Laaka and Marjo Anttila. 1994. Photo H. Vänskä.

to Helsinki for a stay of around five months in 1994. During this time he cut the leaves into pieces and sorted the specimens into genera. Publication of the work on Lejeuneaceae began immediately (Pócs et al. 1994, 1995; Pócs \& Piippo 1999, 2011; Gradstein et al. 2002).

\section{RELAXING}

After months of hard work a holiday was necessary. Initially the idea was that Sacy Pócs would come to Helsinki for a holiday, but then their daughter Kata also wanted to come. Then their son Abel, his wife and their baby boy were added to the group, and finally Kata's friend Paula. Arranging affordable accommodation for such a large group, including myself and Aune Koponen, was demanding. At first our summer cottage at Lake Lohjanjärvi was used as a base for fishing and entertainment. Abel caught a pike. The major focus, however, was a tour around central Finland. First we visited Jouko Rikkinen's summer residence in Saarijärvi (he was a member of the student group in Tanzania) and went to Pyhähäkki National Park. From Saarijärvi we drove to Kuopio, where we met Matti Haapasaari and Jette Lewinsky, had lunch in the revolving restaurant atop Puijo Tower, and overnighted at Haapasaari's summer residence with its smoke sauna. Fishing continued, and Abel caught another pike. From Kuopio we went to Savonlinna, where lodging was arranged in Retretti Holiday Village. In the Retretti exhibition center we saw a Picasso exhibition, and we also visited Aune's sister's sheep farm. The major event was the opera Aida, which we attended as part of the Savonlinna Opera Festival.

After returning to Helsinki Abel's family soon left to go back to Hungary. Tamás and Sacy stayed on for more than a week in Helsinki.

\section{COURSES IN TROPICAL BRYOLOGY}

In 1993, a 'Course in Tropical Bryology' was organized in the University of Helsinki Department of Botany, and in the same year the Department was selected for the Human Capital and Mobility 


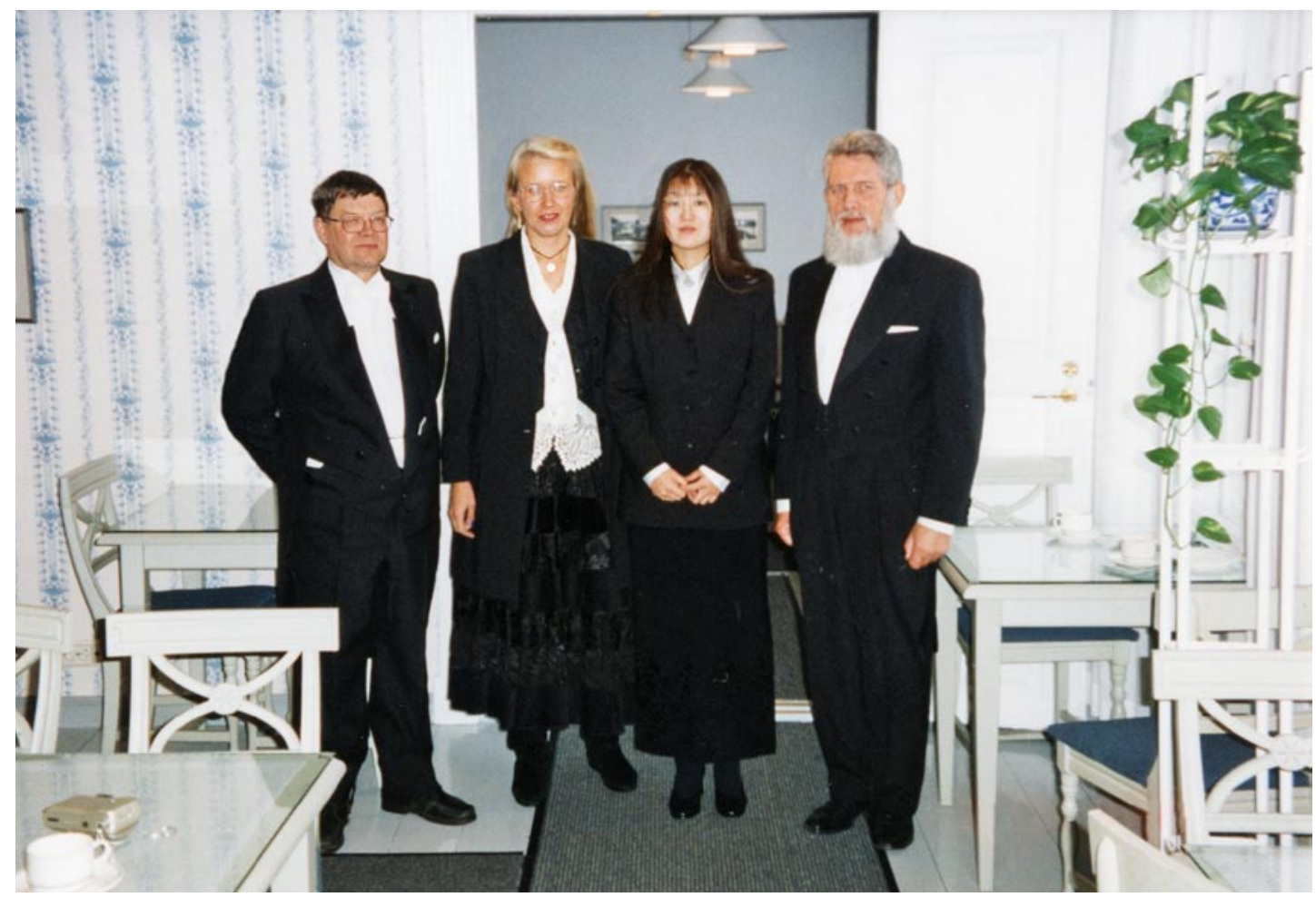

Fig. 4. After the dissertation defense of Xiaolan He in 1999. Timo Koponen, Sinikka Piippo, X. He and Tamás Pócs. Traditionally, the opponent and the custodian are dressed in tails.

program of the EU and was awarded the status of Large Scale Facility for Advanced Instruction in Bryology and Lichenology (Koponen et al. 1993). Several courses were organized, including a new 'Course in Tropical bryology', which was held twice, in 1998 and in 2000 (Kungu 1998; Cairns 2000). Tamás Pócs taught in all three courses. During his stay in Helsinki in 1998, a commemorative 'African Night' gathering was held in the Palm house of the Botanical Garden to thank Tamás once again for his help during the excursions in Tanzania and for his cooperation in teaching and research. All four of the teachers in the first excursion participated, along with many students from the first and later trips (Fig. 3).

Tamás was also invited to Helsinki in 1999. On 29 January he acted as the opponent in Xiao-Lan He's Ph.D. thesis defense in the Division of Systematic Biology (Fig. 4). The subject of the thesis (He 1999) was a genus in the family Lejeuneaceae.
Ten years later, in 2009, Tamás Pócs was elected corresponding member of the Finnish Bryological Society (Piippo 2009).

ACKNOWLEDGEMENTS. Professor Marja Härkönen and Professor Sinikka Piippo reviewed the manuscript. Dr. Neil Bell made linguistic corrections. Many thanks to all of them.

\section{REFERENCES}

Brotherus V. F. 1929. Musci. In: H. HANDEL-MazZetti (ed.), Symbolae Sinicae. Botanische Ergenisse der Expedition der Akademie der Wissenschaften in Wien nach Südwest-China 1914/1918, 4: i-v, 1-147, Tafel i-v. Julius Springer, Wien.

CAIRnS A. 2000. Report on the Tropical Bryology course, Helsinki, April 3-14. 2000. Bryological Times 101: 16-17.

CAO T. \& Koponen T. 2004. Musci in "Symbolae Sinicae"; an annotated checklist of mosses collected by H. HandelMazzetti in China in 1914-1918, and described by V. F. Brotherus in 1922-1929. Bryobrothera 8: 1-34. 
GAO C. \& CAO T. 2010. In memory of Dr. Ming-Jou Lai and our fruitful cooperation in bryological research. Acta Bryolichenol. Asiat. 3: 19-22.

Gradstein R., He X.-L., Piippo S. \& Mizutani M. 2002. Bryophyte flora of the Huon Peninsula, Papua New Guinea. LXVIII. Ledjeuneaceae subfamily Ptychanthoideae (Hepaticae). Acta Bot. Fenn. 174: 1-88.

HÄRKÖNEN M., NIEMELÄ T. \& MwASUMBI L. 2003. Tanzanian mushrooms. Norrlinia 10: 1-200.

HE X.-L. 1999. A taxonomic monograph of the genus Pycnolejeunea (Lejeuneaceae, Hepaticae). Acta Bot. Fenn. 163: $1-77$.

JunikKa L., Schulman L., Mndolwa A. \& Rajabu I. 1998. Trees of Amani Nature Reserve, NE Tanzania. The Ministry of Natural Resources and Tourism, Tanzania, with financial support from the Government of Finland.

Koponen A. 1975. Tayloria pocsii, spec. nova (Musci, Splachnaceae) from Mt. Kilimanjaro, Tanzania. Ann. Bot. Fenn. 12: 22-24.

Koponen A. 1977. Tayloria subgen. Pseudotetraplodon, subgen. nov., and new combinations in Brachymitrion, Moseniella and Tayloria (Splachnaceae, Musci). Ann. Bot. Fenn. 14: 193-196.

KOPONEN T. 1990. Bryophyte flora of Western Melanesia. Tropical Bryol. 2:149-160.

KOPONEN T. 2000. Index of the Bryophyte flora of Western Melanesia. Index to genera and families in parts 1-67, and list of papers. Division of Systematic Biology, University of Helsinki.

KoPOnEn T. 2010. Compilation of "Musci" in "Symbolae sinicae" in the light of H. Handel-Mazzetti's letters to V. F. Brotherus. Bryobrothera 10: 1-78.

KoPONEN T. 2013a. The biography of Professor Risto Tuomikoski. bryologist, entomologist, mycologist, vegetation scientist and ecologist. In: T. KoPONEN, S. PIIPPO \& P. IsOviITA (eds), Professor Risto Tuomikoski Memorial Issue. Bryobrothera 11 (in press).

KOPONEN T. 2013b. Risto Tuomikoski as a bryologist. In: T. Koponen, S. PIIPPO \& P. IsovitTA (eds), Professor Risto Tuomikoski Memorial Issue. Bryobrothera 11 (in press).

Koponen T. \& Hyvönen J. (eds). 1992. Proceedings of the Congress of East Asiatic Bryology, Helsinki, August 1219, 1990. Bryobrothera 1: i-xiii, 1-332.

Koponen T. \& PIIPPO S. 2002. Viktor Ferdinand Brotherus and his collection of letters. Bryobrotherella 5: 1-29.

KOPONEN T. \& WeBER W. A. 1972. A revision of African Tayloriae (Splachnaceae), including Bryomnium. Ann. Bot. Fenn. 9: 126-134.

Koponen T., Ahti T. \& MÄKInEn A. 1993. Department of Botany recognized as the center of bryology and lichenology by the EC. Universitas Helsingiensis 2(1993): 16-19.
Kungu L. 1998. Tropical Bryology Course, Helsinki 24.3.3.4.1998. Bryological Times 96: 10.

LAAKA-LindBERG S. 2004: Bryological notes. Noteworthy terricolous bryophytes on disturbed soil in NE Tanzania. J. Bryol. 26: 301-303.

LEWINSKY J. 1990. Congress of East Asiatic Bryology. Helsinki, August 12-19, 1990. Bryological Times 57/58: 5-8.

MatTila P. \& Koponen T. 1998. The diversity of the bryophyte flora and vegetation on rotten wood in rain and montane forests in northeastern Tanzania. Tropical Bryol. 16: $139-164$

NIEMELÄ T. 2011. Vihreä Afrika. Kasveja ja kasvillisuutta. (Green Africa - plants and vegetation). Norrlinia 23: 1-319.

NuRMI A. (ed.) 1990. Tansania 1988. Helsingin yliopiston kasvitieteen laitoksen opinto- ja tutkimusmatka Tansaniaan joulukuussa 1988. (Vegetation and ecology of montane and rain forest: field excursion of the Department of Botany in Tanzania in December 1988). Publications from the Department of Botany, University of Helsinki 16: 1-119, 3 appendixes.

OrbÁN S. 1979. Conferentia Bryologorum, 5. bis 8. Juni 1978, Eger, Ungarn. Bericht über die erste Konferenz der Moosforscher-Arbeits-Gemeinschaft in den Sozialistischen Ländern. Abstr. Bot. 5 (Suppl. 3): 1-6.

Orbán S. 2003. Pócs Tamás, a trópusi botanikus. Acta Academiae Paedagogicae Agriensis, Sect. Biol. 24: 11-18.

PIIPPO S. 2009. An honorary member and three corresponding members for the Finnish Bryological Society. Bryobrotherella 12: $1-8$.

Pócs T. 1990a. Excursion to the east Usambara Mountains, near Amani. In: A. NuRMI (ed.), Tansania 1988. Helsingin yliopiston kasvitieteen laitoksen opinto- ja tutkimusmatka Tansaniaan joulukuussa 1988. Publications from the Department of Botany, University of Helsinki 16: 97-101.

Pócs T. 1990b. Excursion to the Mount Meru, near Olmotonyi. In: A. NuRMI (ed.), Tansania 1988. Helsingin yliopiston kasvitieteen laitoksen opinto- ja tutkimusmatka Tansaniaan joulukuussa 1988. Publications from the Department of Botany, University of Helsinki 16: 111-116.

Pócs T. 1990c. Arid vegetation between Mkomazi and same at the southwestern foot of the Pare Mountains. In: A. NURMI (ed.), Tansania 1988. Helsingin yliopiston kasvitieteen laitoksen opinto- ja tutkimusmatka Tansaniaan joulukuussa 1988. Publications from the Department of Botany, University of Helsinki 16: 116-117.

Pócs T. 1990d. Excursion to Kimboza Forest Reserve at the Eastern foothills of Uluguru Mountains. In: A. NURMI (ed.), Tansania 1988. Helsingin yliopiston kasvitieteen laitoksen opinto- ja tutkimusmatka Tansaniaan joulukuussa 1988. Publications from the Department of Botany, University of Helsinki 16: 117-119. 
Pócs T. 1992. Correlations between the tropical African and Asian bryofloras. II. Bryobrothera 1: 35-47.

Pócs T. \& PIIPPO S. 1999. Bryophyte flora of the Huon Peninsula, Papua New Guinea. LXIV. Aphanolejeunea (Lejeuneaceae, Hepaticae). Acta Bot. Fenn. 165: 85-102.

PócS T. \& PIIPPO S. 2011. Bryophyte flora of the Huon Peninsula, Papua New Guinea. LXXIV. Cololejeunea (Lejeuneaceae, Hepaticae). Acta Bryolichenol. Asiat. 4: 59-137.

Pócs T., Mizutani M. \& Pirppo S. 1994. Bryophyte flora of the Huon Peninsula, Papua New Guinea. LXV. Preliminary contributions to Lejeuneaceae (Hepaticae) 1. Ann. Bot. Fenn. 31: 179-190.
Pócs T., PiIPPo S. \& Mizutani M. 1995. Bryophyte flora of the Huon Peninsula, Papua New Guinea. LXV. Preliminary contributions on Lejeuneaceae (Hepaticae) 2. Ann. Bot. Fenn. 32: 259-268.

TUOMIKOSKI R. 1958. Über der heutigen Stand der Laubmoosesystematik. Uppsala Universitets Ĺrskrift 6(1958): 65-68.

UKKola T. 1998. Tanzanian Myxomycetes to the end of 1995. Publications from the Department of Botany, University of Helsinki 27: 1-45.

VÁŇA J. 1984. Preface. In: J. VÁŇA (ed.), Proceedings of the Third Meeting of the Bryologists from Central and Eastern Europe. Praha 14th - 18th June 1982, pp. 7-8. Univerzita Karlova, Praha.

Received 7 May 2013 